\title{
Relation of titred peripheral pattern ANA to anti-DNA and disease activity in systemic lupus erythematosus
}

\author{
RAYMOND JAY WEITZMAN* AND SARA ELLEN WALKER
}

From the Rackham Arthritis Research Unit, Department of Internal Medicine, University of Michigan Medic $\overrightarrow{\vec{D}}$ School, Ann Arbor, Michigan, USA

SUMMARY This study compared the clinical usefulness of the peripheral pattern detected in immunofluorescent antinuclear antibody (ANA) testing with anti-DNA measured by the modified Farf technique. 48 patients with active or inactive systemic lupus erythematosus (SLE) were studied at one point in the course of their disease. There was no association between titres of serum giving a peri $\overrightarrow{5}$ pheral ANA pattern (tp-ANA) and anti-DNA values. Tp-ANA did not correlate with activity of SLE. In contrast with this finding, anti-DNA correlated with severity of renal disease, decrease serum complement, and number of SLE criteria. In a separate group of 9 patients with flare-ups SLE, tp-ANA and anti-DNA fell as disease activity was controlled. Nevertheless, these two parä meters were independent of one another. It was concluded that tp-ANA did not accurately reflect anti-DNA or activity of SLE.

Heterogeneous antinuclear antibodies (ANA) are routinely detected using the indirect immunofluorescent technique, and the identification of distinct patterns of fluorescent staining in substrate nuclei may be a useful means of evaluating the clinical status of patients with systemic lupus erythematosus (SLE). The peripheral pattern of nuclear staining is characteristically associated with the presence of serum antibodies directed against DNA (anti-DNA) (Casals et al., 1963). In many patients peripheral nuclear staining correlates with active disease (Gonzalez and Rothfield, 1966; Tan, 1967; Rothfield and Stollar, 1967; Luciano and Rothfield, 1973). This suggests that semiquantitative immunofluorescent ANA tests using increasing dilutions of serum might be used to estimate antiDNA values and evaluate activity of disease in SLE. If specific anti-DNA assays were not available, it could be assumed that a peripheral ANA pattern produced by a high titre of serum reflects raised anti-DNA levels and active SLE.

We compared ANA testing of titred serum with a specific test for double-stranded DNA. 48 patients

Accepted for publication June 4, 1976

Correspondence to Dr. S. E. Walker, R4633 Kresge I, 1405 East Ann Street, Ann Arbor, Michigan 48109, U.S.A.

*Present address: Woodland Medical Center, 22341 West Eight Mile Road, Detroit, Michigan 48219, U.S.A. with active or quiescent SLE were studied at single point in the course of their disease. The highest serum titre giving a peripheral pattern (tp? ANA) was considered the end point in positive immunofluorescent ANA tests. Anti-DNA ant bodies were measured using a modification of the Farr technique (Walker and Bole, 1975). Unexpectedly, tp-ANA did not correlate with anti-DNA values or SLE activity. A separate group of patients with lupus flare-ups were followed serially. to examine the effects of prednisone therapy on serological parameters of disease activity. In these patients tp-ANA and anti-DNA values fell as disease activity was controlled with medication? Nevertheless, there was no correlation betwee tp-ANA and anti-DNA values after treatment was. started. This study provided evidence that ANA tests with peripheral patterns produced by titredo sera do not accurately reflect serum anti-DNA leve or severity of disease in SLE.

\section{Methods}

SLE PATIENTS STUDIED AT RANDOM

48 SLE patients with low, moderate, or high ant 5 DNA levels were selected from the Arthritis Clinio without reference to disease activity or therapy. Af patients fulfilled at least four American Rheumatisn? 
Association criteria for classification of SLE (Cohen et al., 1971). They were ANA-positive on one or more occasions, during the course of disease, but not necessarily at the time of study.

\section{SLE PATIENTS STUDIED SERIALLY}

A separate group of 9 patients was studied because multiple sequential serum samples, including sera with high anti-DNA values, were collected to evaluate disease activity. 8 women and one man, aged 14 to 57 years, were observed for periods of 2 to 7 months. All 9 patients had clinical evidence of renal disease; 8 had biopsy-proven lupus nephritis. Renal biopsy was not performed in one patient. SLE was more active in these 9 patients than in the patients studied at random.

Sera were stored at $-70^{\circ} \mathrm{C}$. Titred ANA tests and anti-DNA determinations were performed using aliquots of the same serum sample from each patient. Retrospective chart review was used to correlate test results with disease activity.

\section{TITRED ANA}

The indirect immunofluorescent procedure described by Friou (1967) and adapted by Kay et al. (1971) was used to test thawed sera for heterogeneous ANA on mouse liver substrate. A single lot of fluoresceinconjugated polyvalent antiserum to human gammaglobulin (Grand Island Biological Company, Grand Island, N.Y.) was used. This antiserum was characterized by a molar $\mathrm{F} / \mathrm{P}$ ratio of 2.5 and protein concentration of $13 \mathrm{mg} / \mathrm{ml}$. The antiserum was diluted $1: 10$ before use. Each serum sample was tested after adding phosphate-buffered saline $\mathbf{p H} \mathbf{7 \cdot 2}$ at dilutions of 1:10, 1:50, 1:100, 1:250, 1:500, and 1:1000. Negative control serum and titred positive control serum were included in each group of tests. The positive control serum was positive consistently with a peripheral pattern in a dilution of $1: 500$.

\section{ANTI-DNA}

Anti-DNA was determined by the modified Farr technique (Walker and Bole, 1975), using ${ }^{14} \mathrm{C}$ labelled KB cell DNA. Spectrophotometric, chemical, and enzymatic characterization indicated that greater than $95 \%$ of the radioactive substrate was doublestranded (Walker and Bole, 1975). In this laboratory binding greater than $20 \%$ reflected raised anti-DNA levels.

\section{RENAL DISEASE}

A renal disease index was derived by assigning values of $0-4$ to increasingly severe azotaemia and increasing amounts of proteinuria. If cellular casts were found in urine sediment, 2 points were added to the total score (Table). Renal status was assessed at the time of anti-DNA and ANA testing. In three instances severity of renal disease could not be scored by chart review.

Table Criteria for quantitation of renal disease in $S L E$ patients

\begin{tabular}{lll}
\hline Points* & $\begin{array}{l}\text { BUN/creatinine } \\
(\mathrm{mg} / 100 \mathrm{ml})\end{array}$ & $\begin{array}{l}\text { Proteinuria } \\
(\mathrm{g} / 24 \mathrm{~h})\end{array}$ \\
\hline 0 & Normal & 0 \\
1 & $21-30 / 1 \cdot 2-2 \cdot 0$ & $0 \cdot 10-0 \cdot 49$ \\
2 & $31-50 / 2 \cdot 1-3 \cdot 0$ & $0 \cdot 50-1 \cdot 49$ \\
3 & $>51 / 3 \cdot 1$ & $>1 \cdot 5$ \\
\hline
\end{tabular}

* Renal disease score was obtained by adding the number of points allotted for abnormal blood urea nitrogen and/or serum creatinine to points for proteinuria. Two points were added to the total score if cellular casts were found in the spun urinary sediment.

Conversion: Traditional units to SI-BUN : $1 \mathrm{mg} / 100 \mathrm{ml} \approx 0.357$ mmol/1. Creatinine: $1 \mathrm{mg} / 100 \mathrm{ml} \approx 88.4 \mu \mathrm{mol} / 1$.

TOTAL HAEMOLYTIC COMPLEMENT

Total haemolytic complement activity (THC) in fresh cold serum was measured by the modified Kent and Fife technique described by Pekin and Zvaifler (1964), using sheep red blood cells $(4.5 \times$ $10^{3} \mathrm{cells} / \mathrm{mm}^{3}$ ) and rabbit antibody as haemolysin. Serum samples for haemolytic complement were usually obtained at the same time or within 48 hours of the time blood was drawn for determination of anti-DNA and titred ANA. In six instances tests for THC were not available. Normal THC values were $104-188 \mathrm{CH}_{50}$ units.

\section{ACTIVITY OF SLE}

A retrospective chart review was made to determine disease activity at the time serum was obtained for ANA and anti-DNA. Clinical activity was graded on a scale of 1-14 depending upon the presence of the following proposed criteria for the classification of SLE: facial erythema, photosensitivity, discoid lupus, alopecia, Raynaud's phenomenon, mucosal ulcers, nondeforming arthritis, serositis, central nervous system involvement, cytopenia, LE cells, false-positive serological test for syphilis, proteinuria, and cellular casts in urine sediment (Cohen et al., 1971). Two modifications of these criteria were used. (1) Any amount of proteinuria was accepted as evidence of renal involvement; (2) A single falsepositive serological test for syphilis was accepted as evidence of disease. Although other manifestations of SLE may have been present in individual patients, they were not included in this assessment of SLE activity. In three instances the presence or absence of diagnostic criteria could not be ascertained by chart review. 


\section{STATISTICAL ANALYSIS}

The MIDAS software package (Fox and Guire, 1973) was used within the MTS system on the AMDAHL 470V/6 computer to calculate linear regression, the correlation coefficient $r$, and $r^{2}$ (Snedecor and Cochran, 1967). Mean values derived from groups with unequal numbers of individuals were compared using the $t$ test described by Snedecor and Cochran (1967). The P value was set at 0.5.

\section{Results}

TP-ANA AND ANTI-DNA IN SLE PATIENTS STUDIED AT RANDOM

In 39 of 48 patients studied at one point in the course of their disease, titred ANA tests were positive and a peripheral pattern was identified on one or more positive slides. In 2 patients a speckled pattern was the only pattern identified in all dilutions of serum tested. Since this study focused on the clinical importance of titred ANA tests with a peripheral pattern, these 2 patients were considered ANAnegative. Sera from 7 patients tested at $1: 10$ dilution were negative. As expected from the work of others (Casals et al., 1963), the mean anti-DNA value in ANA-positive sera (49\%) was greater than anti-DNA in sera with a negative ANA test $(16 \%)$. This difference was significant at the 0.0005 level.

Unexpectedly, there was no linear correlation between tp-ANA and anti-DNA levels. Fig. 1 shows the relation between titres of sera producing a



Fig. 1 Titred serum samples from 39 of 48 SLE patients produced positive ANA tests with a peripheral pattern. The greatest dilutions of serum producing a peripheral pattern (tp-ANA) are plotted against anti-DNA values, expressed as $\%{ }^{14} \mathrm{C}$-labelled DNA bound by $0.010 \mathrm{ml}$ serum. There was no linear relationship between results of these two tests $\left(r^{2}=0 \cdot 15 ; P=0 \cdot 30\right)$. peripheral ANA pattern and anti-DNA values.믕 Individual samples of serum in dilutions ranging: from 1:10 to 1:500 produced a peripherases? pattern on substrate nuclei. In a few instances, wheno higher dilutions of serum were tested a speckledE. pattern was observed. Nevertheless, in this study thes highest titre of serum producing a periphera的 pattern was considered the tp-ANA value. This figure shows that when patients were studied at? random there was no linear relation between $t p-\mathrm{ANA}^{\circ}$ and anti-DNA $\left(\mathrm{r}^{2}=0 \cdot 15 ; \mathrm{P}=0 \cdot 30\right)$. In 12 weakly ANA-positive sera producing a peripheral pattern at a dilution of $1: 10$, a high mean anti-DNA value of $47 \%$ (range $12 \%-96 \%$ ) was found. In $\frac{6}{\omega}$ strongly ANA-positive sera with a peripheraP pattern at 1:500 dilution, mean anti-DNA was $50 \%$ (range $12 \%-95 \%$ ). The lack of correlation between tp-ANA and anti-DNA was clear when patients were divided into 2 groups based upon their anti-DNA responses. 14 patients with normal anti DNA (mean 14\%) had median tp-ANA of $1: 10$ 을 In 34 patients with abnormally high anti-DNA (mean 55\%), median tp-ANA was also 1:10.

\section{TP-ANA AND DISEASE ACTIVITY IN SLE}

\section{PATIENTS STUDIED AT RANDOM}

Fig. 2 shows that tp-ANA values were independents of 3 separate parameters of disease activity in 48 SLE patients studied at random. Renal disease was found in 18 of 38 patients with peripheral patterns $\Phi$

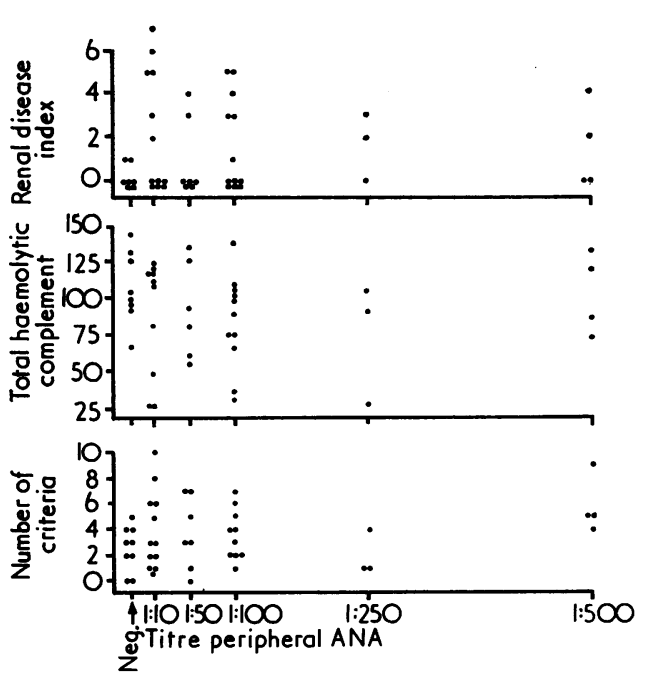

Fig. 2 In 48 patients with SLE studied at random there? was no correlation between $t p-A N A$ and 3 parameters of active disease. Renal disease indices, total haemolytic complement values expressed as $\mathrm{CH}_{50}$ units, and numbers of criteria for classification of SLE were independent of $\mathbb{D}$ titred ANA tests with a peripheral pattern. 
In these 18 patients the mean renal disease index of 3.7 reflected the presence of moderate renal disease. There was no correlation between the magnitude of tp-ANA and the renal disease index $\left(r^{2}=0.00001\right.$; $P=1 \cdot 0)$.

The middle panel in Fig. 2 shows THC values in 42 SLE patients. Mean THC in patients with positive ANA tests was 89 units, and the mean value in patients with negative tests was 108 units. Titred ANA values did not correlate with THC levels $\left(\mathrm{r}^{2}<1.0 \times 10^{-5} ; \mathrm{P}=1.0\right)$. THC values varied from 25 to 135 units in patients with peripheral ANA patterns in serum dilutions ranging from 1:10 to $1: 500$.

The third panel in Fig. 2 shows the relationship between tp-ANA and ARA criteria for the classification of SLE. 36 ANA-positive patients fulfilled a mean number of 3.8 criteria, and 9 patients with negative tests had a mean number of 2.6 criteria. Although a larger number of criteria were found in patients with positive tests compared to patients with negative tests, tp-ANA did not correlate with the number of criteria present at the time of this study $\left(\mathrm{r}^{2}=0 \cdot 04 ; \mathrm{P}=0 \cdot 20\right)$.

\section{ANTI-DNA AND DISEASE ACTIVITY IN SLE} PATIENTS STUDIED AT RANDOM

The relationships between anti-DNA and 3 parameters of disease activity in SLE patients studied at
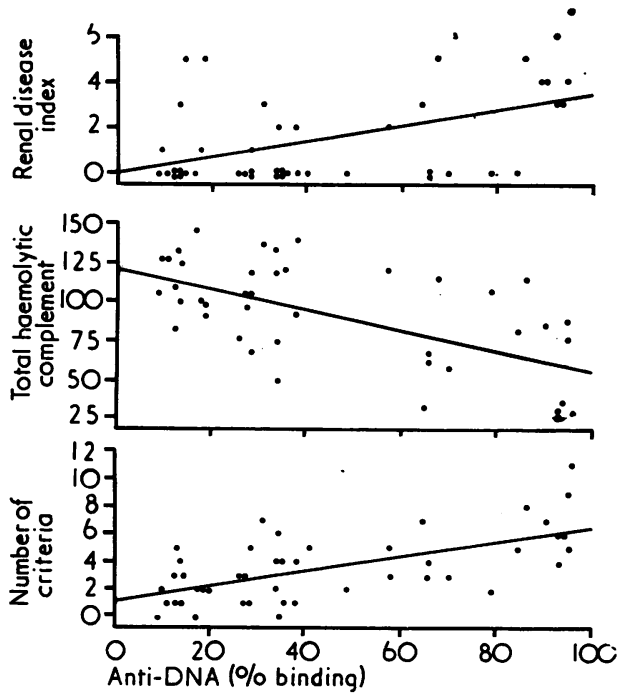

Fig. 3 In contrast to tp-ANA,DNA binding correlated with parameters of active $S L E$. Linear relationships were apparent when anti-DNA was graphed with renal indices $\left(r^{2}=0.2 ; P=0.0004\right)$, total haemolytic complement levels $\left(r^{2}=0.6 ; P<0.00001\right)$, and $S L E$ criteria $\left(r^{2}=\right.$ $0.4 ; P<0.00001)$. random are shown in Fig. 3. In contrast to tp-ANA, DNA binding showed positive correlations with severity of renal disease, decreased THC, and SLE criteria. The upper panel shows the linear relation between the renal disease index and increasing anti-DNA values. Severity of renal disease in these patients increased as a function of anti-DNA $\left(r^{2}=0.2 ; P=0.0004\right)$. The middle panel shows THC and anti-DNA in patients studied at random. Low THC values correlated closely with high antiDNA levels $\left(r^{2}=0.6 ; P<0.00001\right)$. The third panel shows the positive correlation between anti-DNA and the number of ARA criteria identified in 45 patients $\left(r^{2}=0.4 ; P<0.00001\right) .2$ of 13 patients with normal anti-DNA and 19 of 32 patients with raised anti-DNA fulfilled four or more criteria at the time of this study.

TP-ANA AND ANTI-DNA IN SLE PATIENTS STUDIED SERIALLY

Sequential changes in tp-ANA and anti-DNA in 9 patients with SLE are shown in Fig. 4. Three to six samples of sera were obtained from each patient. 7 cases were studied serially while flare-ups were treated with prednisone; only the first and last tp-ANA and anti-DNA values are shown in Fig. 4. When initial serum samples were tested, high tp-ANA titres were associated with raised anti-DNA values in 6 of these 7 patients. The median tp-ANA was $1: 250$ and mean anti-DNA was $85 \%$. As treatment continued disease activity decreased. Median tpANA fell from 1:250 to 1:10 and mean anti-DNA

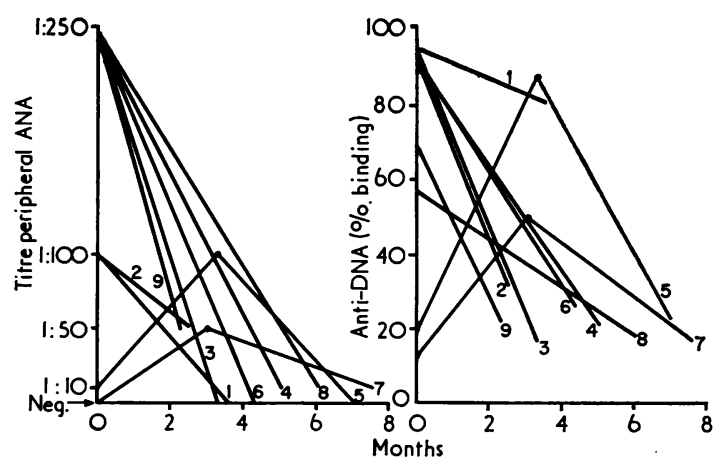

Fig. 49 patients with $S L E$ were studied sequentially. 7 with active disease had decreasing $t p-A N A$ and antiDNA after prednisone therapy was started. 2 patients were followed before, during, and after SLE flare-ups. $T p-A N A$ and anti-DNA increased when disease became active and fell when the flare-ups were controlled with corticosteroids. Although the test values decreased after treatment, tp-ANA was independent of anti-DNA $\left(r^{2}=0.02 ; P=0.30\right)$. 
fell from $81 \%$ to $29 \%$. In 2 instances (Cases 5 and 7) tp-ANA and anti-DNA values were obtained before, during, and after lupus flare-ups. In Cases 5 and 7 tp-ANA and anti-DNA increased when the disease became active. Both values fell when the flare-ups were controlled with prednisone therapy.

Fig. 4 suggests that decreasing tp-ANA correlated with decreasing anti-DNA after treatment for SLE was started. Nevertheless, a linear relationship between both parameters was not proven by statistical methods. Calculations using all test results showed that there was no linear relationship between falling tp-ANA and anti-DNA values in treated patients $\left(r^{2}=0.02 ; P=0.30\right)$. The magnitudes of decreases of serological parameters of disease activity were also studied. In each of the 9 patients observed serially, $\triangle$ tp-ANA (tp-ANA in active disease minus tp-ANA after therapy) and $\therefore$ anti-DNA (anti-DNA in active disease minus antiDNA after therapy) were derived. When $\triangle$ tp-ANA values were plotted against $\triangle$ anti-DNA values, no linear relationship was seen. Calculation of the regression of $\triangle \mathrm{tp}$-ANA on $\triangle$ anti-DNA yielded a $r^{2}$ value of $0.40(P=0.06)$.

\section{Discussion}

This report describes the first study designed to correlate titres of serum producing the peripheral ANA pattern with serum levels of anti-DNA. In 48 SLE patients studied at one point in the course of their disease tp-ANA was not associated with anti-DNA. Patients whose sera produced the peripheral pattern in high titres could not be separated from patients with low titre peripheral patterns on the basis of severity of renal disease, THC levels, or number of SLE criteria fulfilled. 9 patients with SLE were followed serially. When lupus flare-ups were treated with prednisone, both tp-ANA and anti-DNA decreased. Nevertheless, these values did not correlate with one another. It was concluded that titred ANA tests with a rim pattern were not useful in predicting anti-DNA or assessing SLE activity.

The diversity of antibodies directed against DNA and the nonspecific nature of peripheral nuclear staining may explain the lack of association between tp-ANA and anti-DNA in this study. Anti-DNA comprise a spectrum of antibodies directed against diverse antigenic sites within the DNA molecule (Alarcón-Segovia et al., 1970). Anti-DNA measured at one point in time may be specific for one or more nuclear antigens, but only certain antibodies may be responsible for the peripheral pattern.

Casals et al. (1963) reported staining of the outer margins of substrate leucocytes in ANA tests using serum from SLE patients. DNAase incubation $\square$ of substrate cells, incubation of reactive sera with DNA, and testing of antibody recovered from $\overrightarrow{\vec{F}}$ complexed DNA-anti-DNA supported the theory? that anti-DNA was associated with peripheral ANA? staining. This association is valid in many instances. $\frac{\bar{c}}{\bar{c}}$ Nevertheless, information gained from other studies supports the theory that the peripheral pattern is not restricted to patients with SLE who producees antibodies to DNA. Barnett et al. (1966) found the $\vec{\circ}$ peripheral pattern in ANA testing of sera frompatients with Felty's syndrome who did not havew anti-DNA. Another group of investigators studied 101 patients whose sera produced peripheral stainingo (Dorsch et al., 1969). 57 patients had SLE, but 44. patients had other diseases not associated with antiDNA. Bickel et al. (1968) found peripheral nuclear staining in one-fourth to one-third of ANA testso from patients who had neither lupus nor antibodies? to DNA. Tan (1967) reported that the peripheral pattern could be produced by antibodies to soluble nucleoprotein.

This study confirmed the clinical usefulness of anti-DNA determinations. The close correlation $\vec{\theta}$ between anti-DNA levels and renal disease, decreased $y$ THC, and number of SLE criteria in our patients' support the observations of others (Pincus et al.,o 1969) that anti-DNA determinations were valuables in monitoring the activity of lupus. In contrast too anti-DNA, titred tests for ANA with periphera? patterns did not correlate with clinical parameters of active SLE. Indirect immunofluorescent testing for $\overrightarrow{\vec{O}}$ ANA is a sensitive method of screening sera for the presence of autoantibodies. Nevertheless, titred ANA tests are of limited value in assessing SLE activity?

We gratefully acknowledge the technical assistance of Barbara Boddy and Mrs. Cheryl Hassett. THC? was assayed in the Immunology Laboratory, University of Michigan Medical Center, under the direction of Dr. Kathleen P. Heidelberger. The study was supported by a fellowship from the Michigan Chapter of the Arthritis Foundation $\frac{D}{0}$ Grant CA-13297 from the National Cancer Institute, Training Grant AM-05026, and Grant AM-06206 from the National Institutes of Health, USPHS.

\section{References}

Alarcón-Segovia, D., Fishbein, E. Alcalá, H , Olguí Palacios, E., and Estrada-Parra, S. (1970). The range and specificity of antinuclear antibodies in systemic lupuses erythematosus. Clinical and Experimental Immunology; 6, 557-571.

Barnett, E. V., Ruderman, M., Jeannet, M., and Bloch, K.음 J. (1966). Felty's syndrome: occurrence of antibodies and leukocyte agglutinins in 14 patients. Arthritis and Rheumatism, 9, 846 .

$$
\text { 这 }
$$


Bickel, Y. B., Barnett, E. V., and Pearson, C. M. (1968). Immunofluorescent patterns and specificity of human anti-nuclear antibodies. Clinical and Experimental Immunology, 3, 641-656.

Casals, S. P., Friou, G. J., and Teague, P. O. (1963). Specific nuclear reaction pattern of antibody to DNA in lupus erythematosus sera. Journal of Laboratory and Clinical Medicine, 62, 625-631.

Cohen, A. S., Reynolds, W. E., Franklin, E. C., Kulka, J. P., Ropes, M. W., Shulman, L. E., and Wallace, S. E. (1971). Preliminary criteria for the classification of systemic lupus erythematosus. Bulletin on Rheumatic Diseases, 21, 643-648.

Dorsch, C. A., Gibbs, C. B., Stevens, M. B., and Shulman, L. E. (1969). Significance of nuclear immunofluorescent patterns. Annals of the Rheumatic Diseases, 28, 313-319.

Fox, D., and Guire, K. (1973). Documentation for MIDAS, Michigan Interactive Data Analysis System, 2nd ed. Statistical Laboratory, Ann Arbor.

Friou, G. J. (1967). The LE cell factor and antinuclear antibodies. Laboratory Diagnostic Procedures in the Rheumatic Diseases, p. 136. Ed. by A. S. Cohen, Little, Brown, Boston.

Gonzalez, E. N., and Rothfield, N. F. (1966). Immunoglobulin class and pattern of nuclear fluorescence in systemic lupus erythematosus. New England Journal of Medicine, 274, 1333-1338.

Kay, D. R., Bole, G. G., Jr., and Ledger, W. J. (1971). Antinuclear antibodies, rheumatoid factor and C-reactive protein in serum of normal women using oral contraceptives. Arthritis and Rheumatism, 14, 239-248.

Luciano, A., and Rothfield, N. F. (1973). Patterns of nuclear fluorescence and DNA-binding activity. Annals of the Rheumatic Diseases, 32, 337-341.

Pekin, T. J., Jr., and Zvaifler, N. J. (1964). Hemolytic complement in synovial fluid. Journal of Clinical Investigation, 43, 1372-1382.

Pincus, T., Schur, P. H., Rose, J. A., Decker, J. L., and Talal, N. (1969). Measurement of serum DNA-binding activity in systemic lupus erythematosus. New England Journal of Medicine, 281, 701-705.

Rothfield, N. F., and Stollar, B. D. (1967). The relation of immunoglobulin class, pattern of antinuclear antibody, and complement-fixing antibodies to DNA in sera from patients with systemic lupus erythematosus. Journal of Clinical Investigation, 46, 1785-1794.

Snedecor, G. W., and Cochran, W. G. (1967). Statistical Methods, 6th. ed. pp. 104, 141, 172. Iowa State University Press, Ames, Iowa.

Tan, E. M. (1967). Relationship of nuclear staining patterns with precipitating antibodies in systemic lupus erythematosus. Journal of Laboratory and Clinical Medicine, 70, 800-812.

Walker, S. E., and Bole, G. G., Jr. (1975). Selective suppression of autoantibody responses in NZB/NZW mice treated with long-term cyclophosphamide. Arthritis and Rheumatism, 18, 265-272. 